\title{
The Antidemocratic Character of Judicial Review
}

\author{
George Mace*
}

When the Supreme Court declared that institutionalized prayer in a public school violates the establishment clause, ${ }^{1}$ that the failure to apportion either house of a state legislature on a popular basis contravenes the equal protection clause, ${ }^{2}$ and that the refusal to supply counsel during premdictment custodial questioning violates the self-imcrimination clause, ${ }^{3}$ it placed itself at the center of political controversy. Because the Court las the enormous power of judicial review, it is drawn into what would be wholly political matters in most other countries. ${ }^{4}$ It is therefore a natural target of groups who find themselves affected by its decisions.

In this pohtical role, the Court has been nore vulnerable to the onslaught of affected groups than other officials, because its inembers are appointed for life tenure. This would not be of great concern if the judiciary exercised little or no discretion in arriving at decisions, and the process were as simple as Justice Roberts declared in United States v. Butler: ${ }^{5}$

When an act of Congress is appropriately challenged in the courts as not conforming to the constitutional inandate the judicial branch of the Government has only one duty, - to lay the article of the Constitution which is invoked beside the statute which is challenged and to decide whether the latter squares with the former. All the court does, or can do, is to announce its considered judgment upon the question.... This court neither approves nor condemns any legislative policy.

But judicial review clearly involves something other than a simple coinparison of words possessing readily discernible and unchanging ineanings. It is a process of judicial interpretation, a kind of interpretation not far removed from legislation.

* A.B. 1959, Fresno State College; Ph.D. 1964, Claremont Graduate School. Associate Professor of Government, Southern Illinois University at Carbondale.

1. Engle v. Vitale, 370 U.S. 421 (1962).

2. Baker v. Carr, 369 U.S. 186 (1962).

3. Miranda v. Arizona, 384 U.S. 436 (1965). 1948).

4. See A. De Tocoueville, 1 Democracy in AMerica 99 (H. Reeve transl.

5. 297 U.S. 1, 62-63 (1935). 
Given Court decisions that seem to be legislative rulings emanating from judges not held accountable through the electoral process, many have beheved that judicial review is not consistent with the spirit and form of democratic government. This argument has been raised repeatedly throughout the history of the country. One of the earliest advocates of this position was Robert Yates, a judge of the New York supreme court, who wrote the Letters of Brutus. ${ }^{6}$ His opposition to judicial review was not because of the nature and extent of the power but because judges were placed in an unprecedented situation $\mathrm{m}$ a free country: they were totally independent of control by either the people or the legislature, with respect to both their terms of office and their salaries. $^{7}$

The usual answer to this attack on the Supreme Court's independence is that first made in The Federalist by Hamilton. ${ }^{8}$ The crux of the matter turned upon the precautions taken for judicial responsibility. Yates had charged that the Court was responsible to no one and therefore constituted a will imdependent of society. Hamilton did not claim that this was not the case; instead, he attempted to demonstrate an absolute necessity for such a lack of responsibility. Returning to a theme introduced earlier by James Madison, the notion that judicial independence is the best means of preventing tyranny, ${ }^{9}$ Hamilton noted that "[i]n a monarchy it is an excellent barrier to the despotism of the prince; in a republic it is a no less excellent barrier to the encroachments and oppressions of the representative body."10 In short, like separation of powers, judicial review was intended primarily as a check on the otherwise almost unlimited powers of Congress.

It scems curious that the most democratic body of the government was the primary target, especially since The Federalist insisted that the government it explained was wlolly popular. ${ }^{11}$ The answer lies in Madison's behef that, precisely because the majority rules im our pohtical system, we must fear tyranny from below more than above: ${ }^{12}$

6. These were a series of articles that appeared in The New York Journal and Weekly Register during the latter part of 1787 and early 1788. Numbers 11, 12, and 15, which comprise the major attack upon the Court, are reprinted in E. CoRwin, COURT Over CONSTITUTION 231-62 (1957) [hereinafter cited as CORWIN].

7. CORWIN 232, 253, 262.

8. The Federalist No. 78, at 503 (Modern Library) (A. Hamilton) [all cites to The Federalist are to the Modern Library edition].

9. The Federalist No. 48, at 321-23 (J. Madison); No. 49 at 327-33 (J. Madison); No. 51 at 336-37 (J. Madison).

10. The Federalist No. 78, at 503 (A. Hamilton).

11. The Federalist No. 53, at 81; see M. Diamond, The Federalist, in History of Political Phmosophy 581 (L. Strauss and J. Cropsey eds. 1963).

12. The Federalist No. 48, at 322-23 (J. Madison). 
[A minority faction could be checked by] the republican principle, which enables the majority to defeat its sinister views by regular vote. It may clog the administration, it may convulse the society; but it will be unable to execute and mask its violence under the forms of the Constitution. When a majority is included in a faction, the form of popular government, on the other hand, enables it to sacrifice to its ruling passion or interest both the public good and the rights of other citizens. ${ }^{13}$

Because judicial review is to be successful against a majority, it obviously nust be relatively independent of that majority. Any other arrangement would be futile, for a body can hardly be expected to control its controllers. ${ }^{14}$

Furthermore, Hamilton argued, even though judicial review was relatively independent of a majority, this held little threat to the people, since the judiciary could exercise "neither FORCE nor wILL, but merely judgment; and inust ultimately depend upon the executive arm even for the efficacy of its judgments." 15 While it is obvious that the judiciary lacks force, it is not so easy to see that judicial will is only "judgment," and not "will." If the judiciary is to check the legislative branch, it must have a will of its own regardless of whether the success of that check depends upon executive cooperation. What Hamilton apparently ineant is that imsofar as the judiciary must depend upon the executive the Court has no meaningful will, because its dependence Inakes the judicial will imdirectly responsible to the society through the executive.

Unlike The Federalist and all other major essays answering the charge that judicial review is inconsistent with deinocracy, Eugene Rostow sought to show that judicial review is not only consistent with democratic government but is, in fact, democratic. ${ }^{16}$ Initially, Rostow sought

In The Federalist Madison further indicated that the legislature was the primary target of separation of powers in his discussion of the necessity of the executive veto power. However, not even the devices of separation of powers, judicial review, and execntive veto were considered sufficient barriers to the legislature. Further protection was necessary since

it is not possible to give to each department an equal power of self-defence.

In republican government, the legislative authority necessarily predominates.

The remedy for this inconvemence is to divde the legislature into different branches; and to render them, by different modes of election and different principles of aetion, as little conneeted with each other as the nature of their common functions aud their common dependence on the society will admit.

The Federalist No. 51, at 338 (J. Madison). Thus, it was hoped the division of the legislature itself would serve as a further barrier. $I d$.

13. The Federalist No. 10, at 57 (J. Madison).

14. The Federalist No. 78, at 503-11 (A. Hamilton); No. 79, at 512-14.

15. The Federalist No. 78, at 504 (A. Hamilton).

16. Rostow, The Democratic Character of Judicial Review, 66 HARv. L. Rev. 193 (1952) [hereinafter cited as Rostow]. 
to ascertain what things rightfully may be regarded as democratic. $\mathrm{He}$ knew the perplexities involved in that question:

Democracy is a slippery term. I shall make no effort at a formal definition here. Certainly as a matter of historical fact some societies with parliamentary governments have been and are "democratic" by standards which Americans would accept, although it is worth noting that almost all of them employ second chambers, with powers at least of delay, and imdirect devices for insuring continuity in the event of parliamentary collapse, either through the crown or some equivalent institution, like the presidency in France. But it would be scholastic pedantry to define democracy in such a way as to deny the title of "democrat" to Jefferson, Madison, Lincohr, Brandeis, and others who have found the American constitutional system, mcluding its tradition of judicial review, well adapted to the needs of a free society. ${ }^{17}$

It is here that Rostow goes astray, because his definition derives froin arguments by associations that are not legitimate. In the first analogy Rostow implies that there is a similarity between American democracy and British democracy and between the Supreme Court and the British House of Lords. But clearly the aristocratic branch of the British government is not in any way democratic, nor does Rostow intend to say that it is. Rather, he intends to say that the political system of which it is a part is democratic. This confusion between the nature of institutions and the nature of governments continues throughout Rostow's essay. As a result, rather than proving the democratic character of judicial review, or even of the Supreme Court, his endeavors primarily are directed to proving the democratic character of American government. Indeed, even this may be claiming too inuch, because he concludes not that the American political system and judicial review are democratic but that they are "well adapted to the needs of a free society." 18

Rostow's second analogy is based on the supposed beliefs of four democrats: Jefferson, Madison, Brandeis, and Lincoln. Rostow essentially argues that, since these democrats considered our political system "well adapted to the needs of a free society," the system, including judicial review, nnust be democratic. The premise of this argument is the fallacy that what specific men who are democrats approve is democratic. Moreover, the argument contains several other errors: first, Jefferson did not favor judicial review; second, democracy cannot be equated with liberty; and third, these four men did not all consider judicial review democratic.

17. Id. at 199.

18. Id. 
The proof that Jefferson did not favor judicial review is in material Rostow himself cites. First, Rostow quotes this passage from a letter Jefferson wrote to Madison:

In the arguments in favor of a declaration of rights, you omit one which has great weight with ine; the legal check which it puts into the hands of the judiciary. This is a body, which, if rendered independent and kept strictly to their own department, merits great confidence for their learning and integrity. In fact, what degree of confidence would be too much, for a body composed of such men as Wythe, Blair and Pendleton? On characters like these, the 'civium ardor prava pubentium' would make no impression. ${ }^{10}$

Next Rostow wrote:

Jefferson, indeed, went further. He regretted the absence in the Constitution of a direct veto power over legislation entrusted to the judiciary, and wished that no legislation could take effect for a year after its final enactment. Within such constitutional limits, Jefferson beheved, American society could best achieve its goal of responsible self-government. "I have no fear," he wrote, "but that the result of our experiment will be, that men may be trusted to govern themselves without a master."20

For Rostow, these remarks proved that Jefferson favored judicial review, and that it was only later, after Jefferson began to differ with many of the decisions of the Court and to express his disagreement verbally, that he sometimes appeared to repudiate the constitutionality of judicial review itself. ${ }^{21}$

In fact, these remarks show that Jefferson always opposed the form of judicial review that was adopted. The system he preferred would have sought to control the possibility of tyranny from the excessive ardor and passion of the people through a judicial veto and a year's delay in the enactment of legislation. ${ }^{22}$ In his plan, however, either of these controls could have been overridden by two-thirds of both houses of Congress. Thus, he did not favor granting the judiciary final power to determine the constitutionality of congressional legislation, nor did he desire that the federal judiciary review the constitutionality of state legislation. Moreover, Jefferson beheved that each branch of the federal government had an equal duty to use its powers to prevent the federal government froin violatimg the Constitution as that branch imterpreted it. ${ }^{23}$ This explains how Jefferson re-

19. Rostow 198, quoting JefFerson, LIFE AND Selected Writings 462 (Modern Library ed. 1944).

20. Rostow 199.

21. Id.

22. See 6 The Writings of Thomas Jefrerson 387, 393 (A. Lipscomb ed. 1904) [heremafter cited as Lipscomb].

23. Letter to Edward Livingston, in 6 The Writings of Thomas Jefferson 
mained consistent in his later statements that, although the judiciary was "at first considered the most harmless and helpless of all organs," it had developed to the point of "sapping and mining . . . the foundation of the Constitution."24 Jefferson meant that in exercising the power of judicial review, the Court both undermined the rights of the states and enlarged its role within the national government to the point that it violated the principle of separation of powers. Thus, Jefferson clearly did not deem judicial review dernocratic. ${ }^{25}$

Because Rostow fails to adequately define democracy, it is necessary to begin anew at this point. While Rostow is correct in seeing the difficulties inherent in defining the term, there is an essential aspect of democracy without which no forn of government is democratic: majority rule. For Jefferson,

[t]he first principle of republicanism is that the lex majoris partis is the fundamental law of every society of imdividuals of equal rights; to consider the will of the society enounced by the majority of a single vote as sacred as if unanimous, is the first of all lessons in importance, yet the last which is thoroughly learnt. This law once disregarded, no other remains but that of force, which ends necessarily in military despotism. ${ }^{26}$

In another place he noted that all "governments are more or less repubhican, as they have more or less the element of popular election and control in their composition . . . ..22

Applying his criteria to the government of his own state, he found that the purest republican features . . . is the House of Representatives. ... The Executive still less, because not chosen by the people directly. The judiciary [is] seriously anti-republican, because [appointed and] for life. . . .28

The overwhelming majority of political commentators provide us with comments wholly compatible with Jefferson's. For example, Madison distinguished between a republic and a democracy in this manner: "A pure democracy ... [is] a society consisting of a small number of citi-

95 (P. Ford ed. 1892-99) [hereinafter cited as Ford]; Letter to Mrs. John Adams, in 8 Ford 311 and 4 The Writings of Thomas JefFerson 561 (H. Washington ed. 1861) [hereinafter cited as Washington].

24. 7 Washington 404 .

25. As with Jefferson, examination of the statements of Madison and Lincoln indicate that judicial review is directed primarily against the inajority. For Madison's statements, see e.g., The Federalist No. 10, at 59 (J. Madison); No. 57 at 370. For Lincoln's statements, see, e.g., Lincoln, First Inaugural Address, in 8 MEssages and Papers of the Presidents 3210-11 (J. Richardson ed. 1897); Rostow 199 \& n.11. 26. 10 Ford 89; 7 Washington 75. See also 7 Ford 417; 10 Ford 24; 6 Washington 591.

27. 10 Ford $31 ; 6$ Washington 608 .

28. 10 Ford 29; 6 Washington 606 . 
izens, who assemble and administer the government in person . . .."20 In terms of governmental form, the great point of difference between a democracy and a republic is "the delegation of the government, in the latter, to a sinall number of citizens elected by the rest . . .."30 As there are differences, there are also similarities, the major one being the principle of majority rule. And, as with Jefferson, majority rule was held to be the republican principle. ${ }^{31}$

Of the surfeit of commentary on the contemporary meaning of democracy and its contradistinction from republic, perhaps no statement is more representative of or pertinent to our contemporary understanding than that of David Spitz:

[W]e hear, again and again, with the dull and insipid monotony of a broken record, the refrain: "The Umited States is a Republic, not a Democracy." In archaic usage, this is technically correct; the word democracy referred to the direct participation of the citizens in the general affairs of government, while the word republic referred to a systein of indirect or representative government. But in the very large and geographically dispersed modern state, direct democracy is a physical impossibility. Hence, through the normal evolution of language, common usage today employs democracy to mean precisely what republic once ineant. ${ }^{32}$

Democracy means today what republic meant to the founding fathers, and democracy obtains a fundamental prerequisite part. "Majority rule, that is to say, is the mescapable necessity of the democratic state ...."33

The most thought-provoking material Rostow presented in this regard was his suggestion that the task of democracy was to assure the ultimate responsibility of the people for the acts of their appointed and elected representatives. In the case of the Court and judicial review, he argued:

[T] he final responsibility of the people is appropriately guaranteed by the provisions for amending the Constitution itself, and by the benigu influence of time, which changes the persolmel of courts. Given the possibility of constitutional anendment, there is nothing undemocratic in having responsible and independent judges act as important constitutional mediators. For judges deciding ordinary litigation, the ultimate responsibility of the electorate has a special meaning. It is a responsibility for the quality of the judges and for

29. The Federalist No. 10, at 58-59 (J. Madison).

30. Id. at 59.

31. Id. at 57.

32. D. Spitz, Patterns of ANTI-Democratic Thought 8-9 (1965) [hereinafter cited as SPITZ].

33. Id. at 31 . 
substance of their instructions, never a responsibility for their decisions in particular cases. ${ }^{34}$

At first glance, the factor of changes in personnel is hardly to the point and little more than a makeweight argument. Replacing one man with another does not make the second any more responsible than the first, unless provisions are introduced to secure his responsibility. Perhaps what Rostow had in mind was the possible indirect responsibility to the electorate that can stem from the power of Congress and the President to enlarge the Court and appoint new Justices. Indeed, the mere threat to exercise this power was responsible, many believe, ${ }^{35}$ for the Supreme Court's doctrinal shift in West Coast Hotel Co. v. Parrish. ${ }^{36}$ But even though new Justices lolding views similar to the President, Congress, and by extension, a popular inajority, can be placed upon the Court to override the old Justices, once the new Justices are sworn in they become just as independent as the old and as little likely to reflect the wishes of a future inajority. Therefore, this process does not make the Court entirely democratic unless it is presumed that eacl Court decision would be evaluated by Congress and the President, and if they disagreed, the Court would be enlarged and a new majority appointed. It is more likely that what Rostow actually had in mind was not the possibility of Court-packing but the appointment in the ordinary course of replacement, as he noted, "It is hardly characteristic of law in democratic society . . . to allow appeals from the courts in particular cases to legislatures or mobs."37 This, however, in no way touches the matter of the responsibility of judges to the people.

Rostow's second argument is that the "possibility of constitutional amendment" ultimately makes judicial review democratic. By focusing on the possibility of amendinent, Rostow himself indicated awareness of the difficulties involved in the amendinent process and the unlikelihood of checking the Court througl this method. But even apart froin these difficulties, the amendinent process does not make the Court entirely accountable unless the amendinent is to alter the nature of the Court. The only amendinents that really matter would be those making the Court directly accountable through suffrage or even amending the Court out of existence. However, that the means exist to make the Court democratic does not mean that the Court in present form is democratic. Moreover, even this does not prove that the Court is not a will

34. Rostow 197. It ought to be noted that Supreme Court Justices are arbitrators, not mediators.

35. See, e.g., R. Tresolini, American Constirutional Law 20 (1959).

36. 300 U.S. 379 (1937). See generally Leuchtenburg, The Origins of Franklin

D. Roosevelt's "Court-Packing" Plan, 1966 SuP. CT. REv. 347.

37. Rostow 197. 
independent of a majority of society. In order to propose an amendment to the Constitution, two-thirds of each house of Congress must agree to the proposal or the legislatures of two-thirds of the states must request a convention to propose amendments. To ratify an amendment, the legislatures or conventions of three-fourths of the states must give approval. Therefore, no simple majority could initiate or realize a constitutional amendment. ${ }^{38}$

Thus, even considering this indirect control, the Court can be seen as antidenocratic, if it is correct to assume that majority rule is the crucial factor of the democratic state. However, this is not to say that checks against the majority are bad. Not only are they both good and essential, they also demonstrate that the majority ultimately rules in our system. To see this, we inust accept that soine denocracies can be bad. Aristotle was one of the first to note this distinction clearly. For him, the crucial difference between good and bad forms of democracy-as between good and bad forms of monarchy and aristocracy-did not turn upon the kinds of offices held by citizens nor upon the accidental basis of number, but upon the idea of social class. ${ }^{30}$ Accordingly, bad denocracy, which he denominated dennocracy, was rule by the many in the interest of the poor rather than in the interest of the whole people. ${ }^{40}$ On the other hand, good democracy, denominated polity, was rule by the many in the interest of the whole people. ${ }^{41}$ It is this latter sort of government that present-day Americans regard as our form of government.

Since a minimum requisite of good democracy is that the governinent be responsive to the interests of the whole people, there are at least two reasons why suffrage is necessary. First, history has demonstrated that governments not held accountable through elections have been less responsive to the people. Second, a good deinocratic government inust be directed to the interest of the whole people. There is no guarantee that any government can determine what the interest of the whole people is. Therefore, some kind of protection is needed to prevent a government that, though honestly directed to the interest

38. This has always been true. Based on the census figures of 1790 [see U.S. Census OfFice, 1st Census, 1790, at 3 (1791)], four of the original 13 states with less than 10 percent of the population $(352,354)$ could have prevented the remaining nine states with more than 90 percent of the population $(3,285,527)$ from amending the Constitution. On the other hand, the 10 states with the smallest populations comprised almost 57 percent of the total population. Thus, an amendment had to carry states possessing between a minimal 57 percent to a maximal 94 percent of the population.

39. ARISTOTLE's PoLITICs 140-41 (Modern Library ed. 1943) [hereinafter cited as ARISTOTLE].

40. ARIStotlle 139.

41. Id. 
of the whole people, might monolithically determine that something is in the general interest and seek to impose it upon the country. This has led some to believe that good democracy is merely process. Abraham Kaplan, for example, argues:

We are characters in search of an author, while the greatness of the drama hes just in this: that the characters themselves take over the plot. Deinocracy ineans that you carry no banner but your own. ${ }^{42}$

But good democracy is not just some way of arriving at social policy; it is a very special kind of way. Nor is it just suffrage providing for responsiveness to every deinand of the majority; it is also compromise to reacli consensus in the interest of the whole people. This is the interest that Kaplan and others overlook in arguing that democracy is process alone.

Thus, although process plays an essential role, that role is not the whole of the matter. A good democratic government is directed to the interest of the whole people; and, in our good democratic system, the agency ultimately charged with the proteetion of that interest is the Supreme Court. Resistance to the other branches of government when they act tyrannically, whether because they refuse to reflect the will of the majority or because they do reflect the will of a tyrannical majority, is the constitutionally imposed duty of the judiciary. Since to resist a majority the judiciary must be independent of that majority, the character of judicial review is properly antidemocratic. In this way, it is the primary means whereby the founding fathers expected " $[t]$ o secure the publio good, and private rights, against the danger of sucle a faction, and at the saine time to preserve the spirit and form of popular government....."*3

To the extent that the Court is antidemocratic, the political system of which it is a part is less democratic. But this is true of all governments in historical fact. Even Athenian democracy does not qualify as wholly denocratic; although the whole body of male citizens formed the assembly, this body only had a minor role in the formation and discussion of policy. Real governments are not wholly democratic but only denocratic to a degree depending upon how close they fall near the pure end of the continuum. Thus, it might be correct to say that our government is less democratic than, for example, the Swiss Cantons; but it would not be correct to say our government is not democratic.

It appears that the feelings of guilt concerning judicial review are not justified simply beeause that power is antidemocratic. This fact does not make the system of which it is a part undemocratic. What it does is to help make it a good democracy.

42. Kaplan, The Great Journey, SATURDAX REV., Dec. 23, 1961, at 26.

43. The Federalist No. 10 at 56-57 (J. Madison). 


\title{
California Law Review
}

\begin{tabular}{lll}
\hline \hline VoL. 60 & JUNE 1972 & No. 4 \\
\hline \hline
\end{tabular}

\section{BOARD OF EDITORS}

\author{
Editor-in-Chief \\ DenNis S. KarJazA \\ Managing Editor \\ DAVID L. HAMMETT
}

\begin{abstract}
Notes \& Comments ROBERT C. BARRETT LAWRENCE R. BROWN Thomas D. Clark HENRY C. EAMES, JR. AUBAN ANN EISENHARDT JAMES C. FOWLER ElatNe T. Nelson ROBERT K. SCHIEBELHUT
\end{abstract}

Managing Harold G. FrIEDMaN SCOTT R. WILLERT

Supreme Court Editor Carol G. HammetT

\section{Associate Editors}

DAVID M. ACHTERKIRCHEN MARTIN Basiszta Jown F. DAVIS CHARLEs R. FARrar, JR.

JEFPREY M. ALLEN Michael J. Baker ALICE M. BEASLEY STEVEN S. Bell Michael J. BertinetTi Marsha Siegel Berzon DAVID F. BOYLE Gabrielle R. Campbell WIILIAM F. CAPPS Craig H. Casebeer RAYMOND A. DiAZ Joseph P. DiCiuccio
WENDELL H. GODDARD Calvin R. Grigsby ROBERT L. HARRIS

MARR S. DODSON PAUL E. Dorroh JAMES DRUMMY IRA MARK ELLMAN KenNeth JAMEs Fishbach, JR. DANIEL J. LEER ERNESTINE FORREST Howard W. Foss, JR. DAVID M. GLASS Peter Grossman ANN HASSE LESLIE ANN JOHNSON RICHARD KALISH

Administrative Assistant Patricia G. SMith
Articles \& Book Reviews JIMMIE HARRIS LXNN H. PASAHOW REX PERSCHBACHER StePhen ZAMORA

Research SteVen A. Brick Richard Marcus

ThOMas M. MURRAY LANCE JAY ROBBINS ZONA SAGE MARK HAROLd SHENField

JACK H. KAUFMAN, JR. KEVIN F. KELIEY STEPHEN L. KOSTKA LARY LAWRENCE PALMER BROWN MADDEN Craig D. Muller THOMAS E. RANKIN Lee Charles Rosenthal Cratg M. Thomas JOHN E. THORSON STEPHEN J. YODER 